10 - ORIGINAL ARTICLE

SYSTEMATIC REVIEW/META-ANALYSIS

\title{
System evaluation on reamed and non-reamed intramedullary nailing in the treatment of closed tibial fracture ${ }^{1}$
}

\author{
Chun-xiao Li', Hong-jing Zhao', Wan-qiu Zhao', Yong-qing Xü \\ IFellow PhD degree, Department of Orthopedics, Kunming General Hospital, Chengdu Military Area Command, China. \\ IIPhD, Department of Orthopedics, Kunming General Hospital, Chengdu Military Area Command, China.
}

\begin{abstract}
PURPOSE: To systematically evaluate the clinical efficacy of reamed and nonreamed intramedullary nailing in treatment of closed tibial fractures with Cochrane systematic review methods.

METHODS: According to the Cochrane systematic review methods, literatures were retrieved from Cochrane library, PubMed, EMbase and other database. Randomized controlled trials (RCTs) and quasi-randomized controlled clinical trials about reamed and nonreamed intramedullary nailing in the treatment of closed tibial fractures were collected and RevMan 5.0 was chosen for metaanalysis.
\end{abstract}

RESULTS: A total of seven studies were included in this meta-analysis. Reamed intramedullary nailing was better than nonreamed intramedullary nailing in nonunion rate $[\mathrm{P}=0.02, \mathrm{RR}=0.46,95 \% \mathrm{CI}:(0.24,0.91)]$ and implant failure rate $[\mathrm{P}<0.0001, \mathrm{RR}=$ $0.36,95 \% \mathrm{CI}:(0.22,0.57)]$. No statistically significant difference was observed in malunion rate, compartment syndrome rate, postoperative infection $[\mathrm{P}=0.18, \mathrm{RR}=0.50,95 \% \mathrm{CI}:(0.18,1.383) ; \mathrm{P}=043, \mathrm{RR}=0.77,95 \% \mathrm{CI}:(0.40,1.48) ; \mathrm{P}=0.27, \mathrm{RR}=0.38$, 95\% CI: $(0.01,7.87)]$.

CONCLUSION: Compared with the nonreamed intramedullary nailing, reamed intramedullary nailing can lead to better outcome in the treatment of closed tibial fractures.

Key words: Tibial Fractures. Fracture Fixation, Intramedullary. Meta-Analysis. Review. 


\section{Introduction}

Tibia fractures are common orthopedic disease ${ }^{1}$. They can be divided into open and closed types according to the soft-tissue injury. There are surgical and non-surgical treatments. Although cast treatment of stable tibial fractures has traditionally been successful, recent clinical studies have shown that intramedullary nails may be more advantageous for fracture healing and function $^{2-3}$.

However, debates remain between reamed and nonreamed intramedullary nailing. The advocates of reaming regard that it can increase the stability of fractures and reamed bone debris can contribute to the fractures as bone graft. Williams et al. ${ }^{4}$ report that a high rate of union (98\%) is achieved with reamed intramedullary nailing. Wiss and Stetson regard that reamed intramedullary nailing is a safe and effective method of treatment for tibial nonunions of previously closed fractures and prior open fractures ${ }^{5}$. The objectors propose that reaming will destroy the blood vessels, increase pressure within the medullary cavity and stimulate the formation of vascular thrombosis ${ }^{6-9}$. Pfister considers that nonreamed nailing is favored especially in German-speaking countries due to slightly simple operation procedure, but it remains the method of first choice for treatment of a hypertrophic non-union of the shaft of the long bones ${ }^{10}$. Krettek recommends nonreamed interlocking nailing for closed tibial fractures with severe soft tissue injury because of low infection and low nonunion rate ${ }^{11}$.

In recent years, some studies have compared the outcomes of reamed and nonreamed intramedullary nailing for treatment of closed tibial fractures, but the conclusions are not the same. Therefore, these studies were collected in present study and meta-analysis was used to systematically evaluate the outcome indicators, and thus provide references for clinical applications.

\section{Methods}

The procedures were in accord with the Ethical Committee on Human Experimentation of Kunming General Hospital of Chengdu Military Area Command. Literatures about intramedullary nailing in treatment of closed tibial fractures were retrieved through searching Cochrane library, PubMed and EMBASE until September 2012 and supplemented by manual search and references backtracking. Following words and terms were appointed as keywords or key terms: closed tibial fractures; intramedullary nailing; reamed; unreamed and randomised controlled trials.

\section{Literature inclusion criteria}

(1) Published literatures; (2) adult with closed tibial fractures are object of study; (3) randomized controlled clinical trials (RCTs) or quasi-randomized controlled trials (CCT); nonRCTs, non-therapeutic clinical research and other studies were not included; reamed intramedullary nailing (4) interventions: 1) treatment group received reamed intramedullary nailing; 2) control group received nonreamed intramedullary nailing; (5) complete data including number of cases, number of controls and number of completed trials; (6) basic information and outcome measures: author, magazine and publication date, number of patients and gender, healing, no healing, implant failure rate, compartment syndrome rate, and postoperative infection rate.

\section{Literature quality assessment}

Included studies were assessed according to the inclusion criteria using Jadad scale ${ }^{12}$ in the aspects of study design, patients, interventions and outcome measures. Two reviewers independently screened the literatures and extracted the data. Inconsistency was solved through discussions or by the third reviewer. Jadad score of $\geq 3$ was considered as high-quality.

\section{Data extraction}

Data was extracted with a unified form. Two reviewers independently collected information about number of cases, loss of follow-up, exit of trial and outcome measures.

\section{Statistical analysis}

RevMan 5.0 was used for statistical analysis. Heterogeneity between studies was examined by chi-square test. If there was no significant heterogeneity between studies, a fixed effects model was adopted. If not, a random effects model was used. Relative risk (RR) was calculated for categorical variables and mean difference (MD) for continuous variables. 95\% confidence interval (CI) was provided.

\section{Results}

Basic information

563 literatures were collected and screened through reading title and abstract to remove review, case report, 
observational study, retrospective study and non-RCTs. Finally, seven studies ${ }^{13-19}$ were included in this meta-analysis. Basic information was listed in Table 1.

TABLE 1 - Basic information of the seven studies.

\begin{tabular}{cccc}
\hline Study & Country & $\begin{array}{c}\text { No. of case } \\
\text { (Reamed/ } \\
\text { Unreamed })\end{array}$ & Follow-up time \\
\hline $\begin{array}{c}\text { Court-Brown (1996) } \\
\text { Blachut } \\
(1997)\end{array}$ & England & $25 / 25$ & 1 years \\
$\begin{array}{c}\text { Finkemeier (2000) } \\
\text { Nassif }\end{array}$ & America & $77 / 64$ & 12 months \\
$(2000)$ & America & $25 / 24$ & 19 months \\
$\begin{array}{l}\text { Larsen } \\
(2004)\end{array}$ & Norway & $24 / 25$ & 24 hour \\
Bhandari & Canada, America, and \\
$(2008)$ & Netherlands & $22 / 23$ & 3.8 years \\
Ali (2011) & Iran & $454 / 438$ & 2 \\
\end{tabular}

Meta-analysis results

\section{Postoperative nonunion rate}

A total of five studies ${ }^{13-15,17-18}$ reported nonunion rate. As no heterogeneity between studies was observed $\left(\mathrm{P}=0.54, \mathrm{I}^{2}=\right.$ $0 \%$ ), the fixed effects model was used for analysis. Meta-analysis showed that reamed intramedullary nailing presented a significant lower nonunion rate than nonreamed intramedullary nailing $[\mathrm{P}=$ $0.02, \mathrm{RR}=0.46,95 \% \mathrm{CI}:(0.24,0.91)]$ (Figure 1$)$.

\begin{tabular}{|c|c|c|c|c|c|c|c|c|c|c|c|}
\hline Studv or Subgroup & $\begin{array}{l}\text { Reame } \\
\text { Events }\end{array}$ & $\begin{array}{l}\text { d } \\
\text { Total }\end{array}$ & $\begin{array}{l}\text { Unream } \\
\text { Events }\end{array}$ & $\begin{array}{l}\text { Ied } \\
\text { Total }\end{array}$ & Weight & $\begin{array}{l}\text { Risk Ratio } \\
\text { M-H,Fixed, } 95 \% \text { Cl }\end{array}$ & I Year & & $\begin{array}{r}\text { Risk F } \\
\text { M-H, Fixer }\end{array}$ & $\begin{array}{l}\text { Ratio } \\
\text { ed, } 95 \% \mathrm{Cl}\end{array}$ & \\
\hline Court-Brown 1996 & 0 & 25 & 5 & 25 & $21.1 \%$ & $0.09[0.01,1.56]$ & 1996 & & & & \\
\hline Elachut 1997 & 3 & 73 & 3 & 63 & $12.4 \%$ & $0.86[0.18,4.13]$ & 1997 & & & & \\
\hline Finkemeier 2000 & 0 & 18 & 1 & 14 & $6.4 \%$ & $0.26[0.01,6.01]$ & 2000 & & & & \\
\hline Larsen 2004 & 0 & 22 & 3 & 23 & $13.2 \%$ & $0.15[0.01,2.73]$ & 2004 & & & & \\
\hline Bhandari 2008 & 8 & 454 & 12 & 438 & $46.9 \%$ & $0.64[0.27,1.56]$ & 2008 & & & & \\
\hline Total $(95 \% \mathrm{Cl})$ & & 592 & & 563 & $100.0 \%$ & $0.46[0.24,0.91]$ & & & & & \\
\hline Total events & 11 & & 24 & & & & & & & & \\
\hline \multicolumn{8}{|c|}{$\begin{array}{l}\text { Heterogeneity: } \mathrm{Chi}^{2}=3.10, \mathrm{df}=4(\mathrm{P}=0.54) ;\left.\right|^{2}=0 \% \\
\text { Test for overall effect: } Z=2.24(\mathrm{P}=0.02)\end{array}$} & 0.005 & $\begin{array}{l}0.1 \\
\text { Reamed }\end{array}$ & $\begin{array}{c}10 \\
\text { Unreamed }\end{array}$ & $200^{\circ}$ \\
\hline
\end{tabular}

FIGURE 1 - Forest plot of nonunion rate for reamed and nonreamed intramedullary nailing. 


\section{$\underline{\text { Postoperative malunion rate }}$}

Three studies ${ }^{13-14,17}$ provided postoperative malunion rate. Since no heterogeneity between studies was observed ( $\mathrm{P}$ $=0.18, \mathrm{I}^{2}=8 \%$ ), the fixed effects model was used for analysis. No significant difference was observed in malunion rate between reamed and nonreamed intramedullary nailing $[\mathrm{P}=0.18, \mathrm{RR}=$ 0.50, 95\% CI: $(0.18,1.38)]$ (Figure 2).

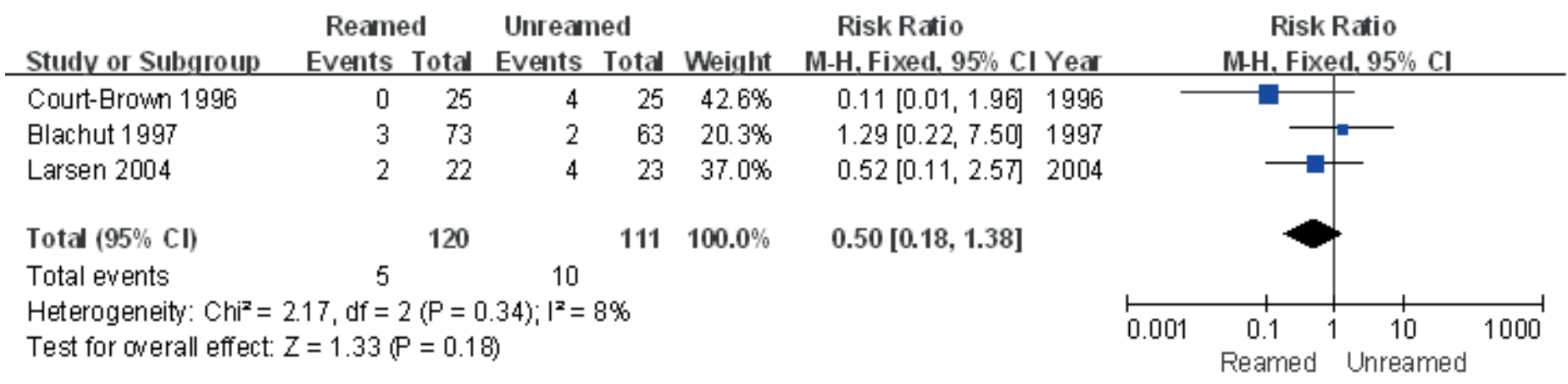

FIGURE 2 - Forest plot of malunion rate for reamed and nonreamed intramedullary nailing.

\section{$\underline{\text { Postoperative implant failure rate }}$}

Five studies ${ }^{13-15,17-18}$ provided postoperative implant failure rate. Since no heterogeneity between studies was observed $\left(\mathrm{P}=0.47, \mathrm{I}^{2}=0 \%\right)$, the fixed effects model was used for analysis. According to meta-analysis, reamed intramedullary nailing showed a significantly lower implant failure rate than nonreamed intramedullary nailing $[\mathrm{P}<0.0001, \mathrm{RR}=0.87,95 \% \mathrm{CI}:(0.78$, 0.98)] (Figure 3).

\begin{tabular}{|c|c|c|c|c|c|c|c|c|c|c|c|}
\hline Studv or Subgroup & $\begin{array}{l}\text { Reame } \\
\text { Events }\end{array}$ & $\begin{array}{l}\text { d } \\
\text { Total }\end{array}$ & $\begin{array}{l}\text { Unrean } \\
\text { Events }\end{array}$ & $\begin{array}{l}\text { ed } \\
\text { Total }\end{array}$ & Weight & $\begin{array}{c}\text { Risk Ratio } \\
\text { M-H,Fixed, 95\% C }\end{array}$ & Year & \multicolumn{4}{|c|}{$\begin{array}{c}\text { Risk Ratio } \\
\text { M-H, Fixed, } 95 \% \mathrm{Cl}\end{array}$} \\
\hline Court-Brown 1996 & 1 & 25 & 14 & 25 & $23.0 \%$ & $0.07[0.01,0.50]$ & 1996 & & - & & \\
\hline Blachut 1997 & 7 & 73 & 12 & 63 & $21.2 \%$ & $0.50[0.21,1.20]$ & 1997 & & & & \\
\hline Larsen 2004 & 1 & 22 & 3 & 23 & $4.8 \%$ & $0.35[0.04,3.10]$ & 2004 & & & & \\
\hline Bhandari 2008 & 13 & 454 & 29 & 438 & $48.5 \%$ & $0.43[0.23,0.82]$ & 2008 & & & & \\
\hline Ali 2011 & 0 & 30 & 1 & 30 & $2.5 \%$ & $0.33[0.01,7.87]$ & 2011 & & & & \\
\hline Total $(95 \% \mathrm{Cl})$ & & 604 & & 579 & $100.0 \%$ & $0.36[0.22,0.57]$ & & & & & \\
\hline Total events & 22 & & 59 & & & & & & & & \\
\hline $\begin{array}{l}\text { Heterogeneity: } \mathrm{Chi}^{2}= \\
\text { Test for owerall effect }\end{array}$ & $\begin{array}{l}55, \mathrm{df}=4 \\
=4.28(\mathrm{~F}\end{array}$ & $\begin{array}{l}(P=0 \\
\leqslant 0.0\end{array}$ & $\begin{array}{l}0.47) ;\left.\right|^{2}= \\
001)\end{array}$ & & & & & 0.01 & $\begin{array}{l}0.1 \\
\text { Reamed }\end{array}$ & $\begin{array}{c}10 \\
\text { Unreamed }\end{array}$ & 100 \\
\hline
\end{tabular}

FIGURE 3 - Forest plot of postoperative implant failure rate for reamed and nonreamed intramedullary nailing. 


\section{Postoperative compartment syndrome rate}

Six studies ${ }^{13-18}$ described postoperative compartment syndrome rate. Since no heterogeneity between studies was observed ( $\left.\mathrm{P}=0.74, \mathrm{I}^{2}=0 \%\right)$, the fixed effects model was used for analysis. No significant difference existed in postoperative compartment syndrome rate between reamed and nonreamed intramedullary nailing $[\mathrm{P}=0.43, \mathrm{RR}=0.77,95 \% \mathrm{CI}:(0.40,1.48)]$ (Figure 4).

\begin{tabular}{|c|c|c|c|c|c|c|c|c|c|c|}
\hline Studv or Subgroup & $\begin{array}{l}\text { Reame } \\
\text { Events }\end{array}$ & $\begin{array}{l}\text { d } \\
\text { Total }\end{array}$ & $\begin{array}{l}\text { Unrean } \\
\text { Events }\end{array}$ & Total & Weight & $\begin{array}{c}\text { Risk Ratio } \\
\text { M-H,Fixed, 95\% Cl }\end{array}$ & & & $\begin{array}{c}\text { Risk Ratio } \\
\text { M-H, Fixed, 95\% Cl }\end{array}$ & \\
\hline Court-Brown 1996 & 2 & 25 & 3 & 25 & $15.9 \%$ & $0.67[0.12,3.65]$ & 1996 & & & \\
\hline Blachut 1997 & 0 & 73 & 3 & 63 & $20.0 \%$ & $0.12[0.01,2.35]$ & 1997 & & & \\
\hline Finkemeier 2000 & 1 & 25 & 1 & 24 & $5.4 \%$ & $0.96[0.06,14.50]$ & 2000 & & & \\
\hline Nassif 2000 & 0 & 24 & 0 & 25 & & Not estimable & 2000 & & & \\
\hline Larsen 2004 & 4 & 22 & 4 & 23 & $20.8 \%$ & $1.05[0.30,3.67]$ & 2004 & & & \\
\hline Bhandari 2008 & 7 & 454 & 7 & 438 & $37.9 \%$ & $0.96[0.34,2.73]$ & 2008 & & & \\
\hline Total $(95 \% \mathrm{CI})$ & & 623 & & 598 & $100.0 \%$ & $0.77[0.40,1.48]$ & & & & \\
\hline Total events & 14 & & 18 & & & & & & & \\
\hline \multicolumn{8}{|c|}{$\begin{array}{l}\text { Heterogeneity: } \mathrm{Chi}^{2}=1.95, \mathrm{df}=4(P=0.74) ; \mathrm{I}^{2}=0 \% \\
\text { Test for owerall effect: } Z=0.79(P=0.43)\end{array}$} & 0.001 & $\begin{array}{ccc}0.1 & 1 & 10 \\
\text { Reamed } & \text { Unreamed }\end{array}$ & 1000 \\
\hline
\end{tabular}

FIGURE 4 - Forest plot of postoperative compartment syndrome rate for reamed and nonreamed intramedullary nailing.

\section{$\underline{\text { Postoperative infection rate }}$}

Four studies ${ }^{14-15,17,19}$ provided information about postoperative infection. As no heterogeneity between studies was observed $\left(\mathrm{P}=0.94, \mathrm{I}^{2}=0 \%\right)$, the fixed effects model was used for analysis. No significant difference was observed in postoperative infection rate between reamed and nonreamed intramedullary nailing $[\mathrm{P}=0.27, \mathrm{RR}=0.38,95 \% \mathrm{CI}$ : $(0.07,2.13)]$ (Figure 5).

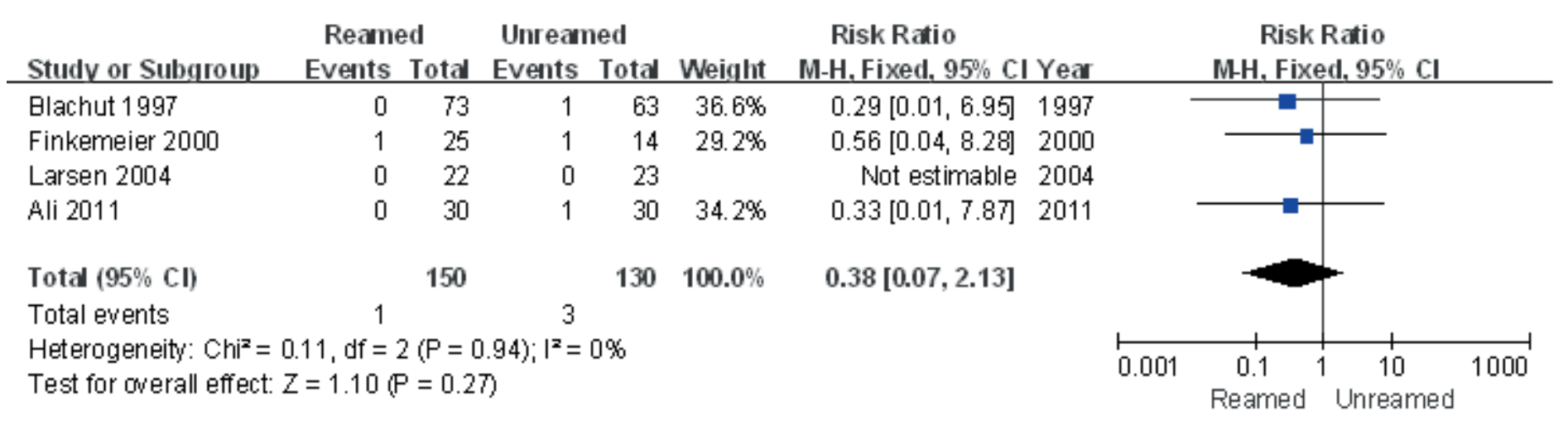

FIGURE 5 - Forest plot of postoperative infection rate for reamed and nonreamed intramedullary nailing. 


\section{Healing time}

Only two studies ${ }^{9}$ reported healing time. However, the studies by Court-Brown et al. ${ }^{13}$ and Sadighi et al. ${ }^{19}$ just provided average healing time, 12 weeks and 20 weeks for reamed, and 22.8 weeks and 24 weeks for nonreamed. Considerable difference was seen between both studies. Since standard deviation was not available, meta-analysis was not conducted.

\section{Discussion}

This systematic review set clear inclusion and exclusion criteria and all the seven included studies were prospective RCTs. Methods for allocation concealment and blinding was described in only one study, and random method was not provided. Three studies reported no loss of follow-up. Only one study had Jadad score 5 and the others were 2 , so the quality of study was not good, suggesting some potential bias in the conclusions. Nevertheless, the included RCTs were carried out in several centers and patients were comprised of different races and countries. High homogeneity was observed in age, gender ratio, fracture site, level of fracture, and degree of injury.

According to this meta-analysis, reamed intramedullary nailing is better than nonreamed in postoperative nonunion rate and implant failure rate. However, no significant difference was observed between these two surgical options in malunion rate, compartment syndrome incidence, and postoperative infection. Since the standard deviation of healing time was not provided, it cannot determine the better one in this regard.

Our conclusions are in accordance with previous studies $^{20-23}$. Forster et $a l .{ }^{21}$ report that reamed intramedullary nailing is better than nonreamed in union rate, but no significant difference is observed in the incidence of complications except screw breakage. Bhandari et al. ${ }^{20}$ also find that reamed intramedullary nailing of lower extremity long bone fractures significantly reduces rates of nonunion and implant failure in comparison with nonreamed nailing. Although the process of reaming causes circulatory disturbances in the inner two-thirds of the diaphyseal cortex, it does not impede the formation of external callus ${ }^{24}$. Therefore, a statistically significant difference in healing times between the two surgical options is reported in the study by Anglen and Blue ${ }^{25}$. Besides, reamed intramedullary nailing may obviate the need for additional bone grafting, and allows full weight-bearing and active rehabilitation ${ }^{26}$. Nevertheless, reaming remains as an unsafe factor as it causes disruption to blood vessels, which may bring in more complications ${ }^{27}$. Shepherd et al. ${ }^{28}$ report that unreamed femoral intramedullary nailing involves fewer steps and is significantly faster with less intraoperative blood loss than reamed intramedullary nailing. However, the advantages of unreaming in blood supply and infection rate could not be proven statistically $^{29}$. Overall, some advantages are certain for reamed intramedullary nailing, for example union rate. However, the difference in other aspects like malunion rate and infection rate is not significant. A precise judgment of the type of tibial fracture is the premise to choose the appropriate surgical option.

Moreover, some limitations existed in present system evaluation. First, six studies had low quality. The number of case receiving two treatments was no more than 50 respectively in five studies, indicating insufficient statistical power. Second, these studies were carried out in different countries with varying medical equipments and technologies, which might affect the judgment of indicators. Third, the follow-up time was different. These factors might influence the reliability of the conclusions. More RCTs with large sample, right methods for random allocation and concealment, detailed report about loss of follow-up and so on are necessary to accurately evaluate the advantage and disadvantage of reamed intramedullary nailing over nonreamed.

\section{Conclusion}

Compared with the nonreamed intramedullary nailing, reamed intramedullary nailing can lead to better outcome in the treatment of closed tibial fractures.

\section{References}

1. Mashru RP, Herman MJ, Pizzutillo PD. Tibial shaft fractures in children and adolescents. J Am Acad Orthop Surg. 2005;13:345-52.

2. Court-Brown CM, Christie J, McQueen MM. Closed intramedullary tibial nailing. Its use in closed and type I open fractures. J Bone Joint Surg Br. 1990;72:605-11.

3. Ekeland A, Thoresen BO, Alho A, Stromsoe K, Folleras G, Haukebo A. Interlocking intramedullary nailing in the treatment of tibial fractures. A report of 45 cases. Clin Orthop Relat Res. 1988:205-15.

4. Williams J, Gibbons M, Trundle H, Murray D, Worlock P. Complications of nailing in closed tibial fractures. J Orthop Trauma. 1995;9:476-81.

5. Wiss DA, Stetson WB. Nonunion of the tibia treated with a reamed intramedullary nail. J Orthop Trauma. 1994;8:189-94.

6. Hupel TM, Weinberg JA, Aksenov SA, Schemitsch EH. Effect of unreamed, limited reamed, and standard reamed intramedullary nailing on cortical bone porosity and new bone formation. J Orthop Trauma. 2001;15:18-27

7. Petrisor B, Anderson S, Court-Brown CM. Infection after reamed intramedullary nailing of the tibia: a case series review. J Orthop Trauma. 2005;19:437-41

8. Gregory P, Sanders R. The treatment of closed, unstable tibial shaft fractures with unreamed interlocking nails. Clin Orthop Relat Res. 
1995(315):48-55.

9. Ochsner PE, Baumgart F, Kohler G. Heat-induced segmental necrosis after reaming of one humeral and two tibial fractures with a narrow medullary canal. Injury. 1998;29 Suppl 2:B1-10.

10. Pfister U. Reamed intramedullary nailing. Orthopade. 2010;39:17181.

11. Krettek C, Schandelmaier P, Tscherne H. Nonreamed interlocking nailing of closed tibial fractures with severe soft tissue injury. Clin Orthop Relat Res. 1995(315):34-47.

12. Jadad AR, Moore RA, Carroll D, Jenkinson C, Reynolds DJ, Gavaghan DJ, McQuay HJ. Assessing the quality of reports of randomized clinical trials: is blinding necessary? Control Clin Trials. 1996;17:1-12.

13. Court-Brown CM, Will E, Christie J, McQueen MM. Reamed or unreamed nailing for closed tibial fractures. A prospective study in Tscherne C1 fractures. J Bone Joint Surg Br. 1996;78:580-3.

14. Blachut PA, O'Brien PJ, Meek RN, Broekhuyse HM. Interlocking intramedullary nailing with and without reaming for the treatment of closed fractures of the tibial shaft. A prospective, randomized study. J Bone Joint Surg Am. 1997;79:640-6.

15. Finkemeier CG, Schmidt AH, Kyle RF, Templeman DC, Varecka TF. A prospective, randomized study of intramedullary nails inserted with and without reaming for the treatment of open and closed fractures of the tibial shaft. J Orthop Trauma. 2000;14:18793.

16. Nassif JM, Gorczyca JT, Cole JK, Pugh KJ, Pienkowski D. Effect of acute reamed versus unreamed intramedullary nailing on compartment pressure when treating closed tibial shaft fractures: a randomized prospective study. J Orthop Trauma. 2000;14:554-8.

17. Larsen LB, Madsen JE, Hoiness PR, Ovre S. Should insertion of intramedullary nails for tibial fractures be with or without reaming? A prospective, randomized study with 3.8 years' follow-up. J Orthop Trauma. 2004;18:144-9.

18. Bhandari M, Guyatt G, Tornetta P, 3rd, Schemitsch EH, Swiontkowski M, Sanders D, Walter SD. Randomized trial of reamed and unreamed intramedullary nailing of tibial shaft fractures. J Bone Joint Surg Am. 2008;90:2567-78.

19. Sadighi A, Elmi A, Jafari MA, Sadeghifard V, Goldust M. Comparison study of therapeutic results of closed tibial shaft fracture with intramedullary nails inserted with and without reaming. Pak J Biol Sci. 2011;14:950-3.

20. Bhandari M, Guyatt GH, Tong D, Adili A, Shaughnessy SG. Reamed versus nonreamed intramedullary nailing of lower extremity long bone fractures: a systematic overview and meta-analysis. J Orthop Trauma. 2000;14:2-9.

21. Forster MC, Bruce AS, Aster AS. Should the tibia be reamed when nailing? Injury. 2005;36:439-44.

22. Xue D, Zheng Q, Li H, Qian S, Zhang B, Pan Z. Reamed and unreamed intramedullary nailing for the treatment of open and closed tibial fractures: a subgroup analysis of randomised trials. Int Orthop. 2010;34:1307-13.

23. Lam SW, Teraa M, Leenen LP, van der Heijden GJ. Systematic review shows lowered risk of nonunion after reamed nailing in patients with closed tibial shaft fractures. Injury. 2010;41:671-5.

24. Kessler SB, Hallfeldt KK, Perren SM, Schweiberer L. The effects of reaming and intramedullary nailing on fracture healing. Clin Orthop Relat Res. 1986(212):18-25.

25. Anglen JO, Blue JM. A comparison of reamed and unreamed nailing of the tibia. J Trauma. 1995;39:351-5.

26. Hak DJ, Lee SS, Goulet JA. Success of exchange reamed intramedullary nailing for femoral shaft nonunion or delayed union. J Orthop Trauma. 2000;14:178-82.
27. Koval KJ, Clapper MF, Brumback RJ, Ellison PS Jr., Poka A, Bathon GH, Burgess AR. Complications of reamed intramedullary nailing of the tibia. J Orthop Trauma. 1991;5:184-9.

28. Shepherd LE, Shean CJ, Gelalis ID, Lee J, Carter VS. Prospective randomized study of reamed versus unreamed femoral intramedullary nailing: an assessment of procedures. J Orthop Trauma. 2001;15:2832.

29. Attal R, Blauth M. Unreamed intramedullary nailing. Orthopade. 2010;39:182-91.

\section{Correspondence:}

Yong-qing $\mathrm{Xu}$

No. 212 Daguan Road

Kunming 650032 China

Phone: 86-0871-64774655

Tax: 86-0871-64774655

xuyongqingxyq@hotmail.com

Received: June 12, 2013

Review: Aug 14, 2013

Accepted: Sept 12, 2013

${ }^{1}$ Research performed at Department of Orthopedics, Kunming General Hospital, Chengdu Military Area Command, Kunming, China. Part of the dissertation of the first author. 